\title{
CHARACTERIZATION OF THE INTERMEDIATE
}

\section{VALUES OF THE TRIANGLE INEQUALITY}

\author{
Kosuke Mineno, Yuka NaKamura And TOMOyoshi OHWAdA
}

Abstract. We shall present a norm inequality which gives the all intermediate values of the triangle inequality. As an application of it, we shall prove two kinds of norm inequalities in [8] and [12].

Mathematics subject classification (2010): Primary 46B20; Secondary 46B99.

Keywords and phrases: Triangle inequalities, normed spaces.

\section{REFERENCES}

[1] A. H. ANSARI AND M. S. MOSLEHIAN, More on reverse triangle inequality in inner products spaces, Int. J. Math. Math. Sci. (2005), no. 18, 2883-2893.

[2] F. Dadipour, M. S. Moslehian, J. M. Rassias and S.-E. Takahasi, Characterization of a generalized triangle inequality in normed spaces, Nonlinear Anal. 75 (2012), no. 2, 735-741.

[3] S. S. DrAGOMIR, Reverses of the triangle inequality in Banach spaces, JIPAM. J. Inequal. Pure Appl. Math. 6(5)(2005), Art. 129, pp. 46.

[4] S. S. Dragomir, Generalizations of the Pečarić-Rajić inequality in normed linear spaces, Math. Inequal. Appl. 12, no. 1 (2009), 53-65.

[5] M. Fujil, M. Kato, K.-S. Saito And T. TAmura, Sharp mean triangle inequality, Math. Inequal. Appl. 13(2010), 743-752.

[6] H. HudziK And T. R. LAndes, Characteristic of convexity of Köthe function spaces, Math. Ann. 294(1992), 117-124.

[7] C.-Y. Hsu, S.-Y. Shaw And H.-J. Wong, Refinements of generalized triangle inequalities, J. Math. Anal. Appl. 344(2008), 17-31.

[8] M. KATO, K.-S. SAITO AND T. TAMURA, Sharp triangle Inequality and its reverse in Banach spaces, Math. Inequal. Appl. 10, no. 2(2007), 451-460.

[9] L. Maligranda, Some remarks on the triangle inequality for norms, Banach J. Math. Anal. 2, no. 2 (2008), 31-41.

[10] M. S. MARTIROSYAN AND S. V. SAMARChYAN, Inversion of the triangle inequality in $\mathbb{R}^{n}$, 38(2003), no. 4, 65-72.

[11] M. S. Moslehian, F. Dadipour, R. Rajić And A. Marić, A glimpse at the Dunkl-Williams inequality, Banach J. Math. Anal. 5, no. 2 (2011), 138-151.

[12] K.-I. Mitani, K.-S. SAito, M. Kato And T. TAMURA, On sharp triangle Inequalities in Banach spaces, J. Math. Anal. Appl. 10, no. 2(2007), 451-460.

[13] K.-I. Mitani, K.-S. SAITO, On sharp triangle Inequalities in Banach spaces II, to appear in J. Inequal. Appl.

[14] S. SAITOH, Generalizations of the triangle inequality, JIPAM. J. Inequal. Pure Appl. Math. 4(2003), no. 3 , Article 62,5 pp. 